DOI 10.15393/j10.art.2016.2861

Наталья Александровна Тарасова

доктор филологических наук, ведущий научный сотрудник Института русской литературы (Пушкинский Дом) РАН (Санкт-Петербург, Российская Федерация) nsova74@mail.ru

\title{
ПРОБЛЕМЫ ПУБЛИКАЦИИ РУКОПИСНОГО ТЕКСТА ДОСТОЕВСКОГО (на материаде черновых рукописей)
}

Аннотация. Статья посвящена проблемам текстологического анализа и публикации черновых рукописей Достоевского - набросков в записных тетрадях и связного чернового текста. В работе приводятся результаты исследования рукописных материалов 1860-1870-х годов к романам «Преступление и Наказание», «Идиот», «Подросток» и «Братья Карамазовы». Подробно рассматриваются научные подходы к проблемам публикации текстов Достоевского, сложившиеся в 1920-е-1930-е годы и получившие развитие в более позднее время, когда сформировалась концепция академического издания произведений Достоевского. На основе этого анализа определяется круг вопросов, имеющих значение для современного достоевсковедения и для новых проектов, книжных и электронных, по изданию текстов писателя.

Ключевые слова: Достоевский, текстология, черновые рукописи, эдиционная практика

B опрос, всегда возникающий при издании рукописей Достоевского, связан с тем, как отражать последовательность текста ${ }^{1}$. В 1920-е-1930-е годы выделились две концепции издания: одна основывалась на принципе воспроизведения записей так, как они расположены на странице; вторая - на изучении хода творческого процесса и допускала возможность перестановки записей при издании текста согласно результатам исследования [15, 8-9].

Н. Л. Бродский, рецензируя сборник Л. П. Гроссмана «Творчество Достоевского (1821-1881-1921)», подчеркивал, что «ничем нельзя оправдать, когда исследователь нарушает порядок следования текста, данный самим писателем, или печатает отрывок, разбивая его целостность случайно выхваченными строками» $[2,436]^{2}$. Речь шла о публикации Л. П. Гроссманом небольших отрывков рукописного текста, включавших план «Жития великого грешника», фрагменты из записной тетради к «Бесам» и др. Замечание Н. Л. Бродского отразило назревавшие 
разногласия в публикаторских подходах, открывшиеся позднее, в 1930-е годы, когда рукописи Достоевского начали печатать в большем объеме и указанные проблемы проявились отчетливее.

Концепция последовательного отражения записей в печати без существенной их перестановки предложена в публикациях И. И. Гливенко [9] и Е. Н. Коншиной [7]. Второй подход разработан П. Н. Сакулиным и представлен в издании рукописей романа «Идиот» [8]. В 1930-е годы эти эдиционные принципы поддержал В. Л. Комарович, полагавший, что «Сакулин справедливо учел невозможность “механически воспроизводить” последовательность в тетрадях и допустил поэтому в своем издании ряд “очень значительных перестановок” ” $[10,265]$. Метод, основанный на воссоздании последовательности творческой работы писателя над текстом, постепенно утвердился в практике научных изданий рукописей Достоевского. Согласно принципам восстановления творческого процесса подготовлены публикации рукописей в сериях «Литературное наследство» (записные тетради) [20]; [12], «Литературные памятники» (роман «Преступление и Наказание») [22] и в академическом издании произведений Достоевского $[4]^{3}$.

В постсоветский период проблемы публикации рукописных материалов сохраняют свое значение ${ }^{4}$. Подготовка современных научных изданий текстов Достоевского [6]; [5], а также разработки в области новейших информационных технологий и методов электронной публикации архивного наследия русских классиков ${ }^{5}$ усиливают необходимость обсуждения этих вопросов.

Анализируя указанные концепции, следует сказать, что возникновение противоположных точек зрения обусловлено тем, что, во-первых, в рукописных текстах Достоевского представлены разные этапы творческого процесса, от набросков до наборной рукописи, во-вторых, к разным произведениям сохранился материал разного состава. Различие в стадиях творческого процесса, различные содержание и состав текстов естественно предполагают вариантность подходов к их исследованию и публикации. Текстологические решения обусловлены спецификой изучаемого материала, который не позволяет производить перестановку записей при публикации. Особенно это касается стадии набросков, работая с которыми, исследователь в большей степени 
рискует произвести ошибочное совмещение разных записей, ибо почти все они имеют характер незавершенности. Не случайно в той же статье, где выражено одобрение методики П. Н. Сакулина, В. Л. Комарович сделал уточнение, упомянув о собственном издании рукописей «Братьев Карамазовых»: «...чтоб отнюдь не навязывать отрывочным записям Достоевского произвольной синтаксической связи, искажающей их смысл, и без того не всегда достаточно ясный, - воспроизводился нами по возможности и порядок размещения текста по рукописной странице; если же воспроизвести его было нельзя, он по крайней мере оговаривался нами в подстрочных примечаньях» [10, 269-270]. Вместе с тем есть примеры, когда Достоевский связывает записи с разных страниц, используя знаки, подобные корректурным (фактически указывая на соединение записей), и в этом случае следовать принципу постраничного воспроизведения текста становится затруднительно.

Так, в записной тетради с черновой редакцией романа «Преступление и Наказание» (РГАЛИ. Ф. 212.1.4) в конце с. 109 стоит знак \#:

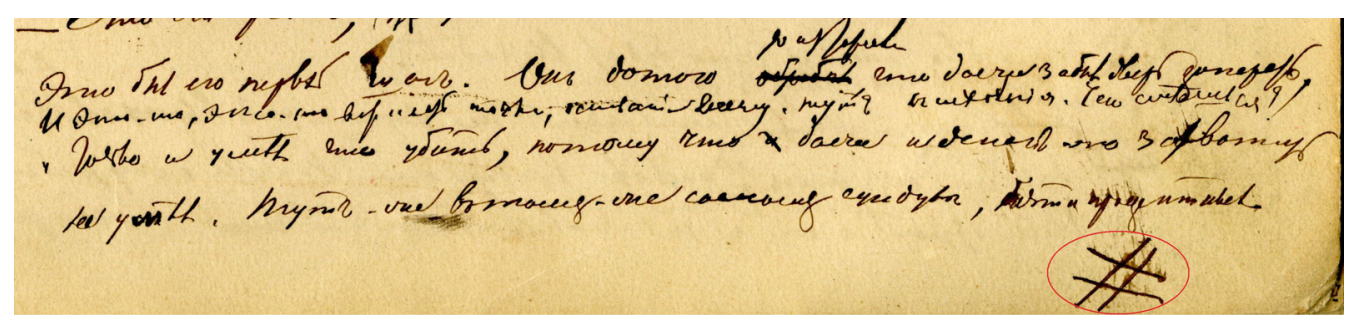

Илл. 1

Продолжение текста под соответствующим знаком находится на c. 27 той же тетради:

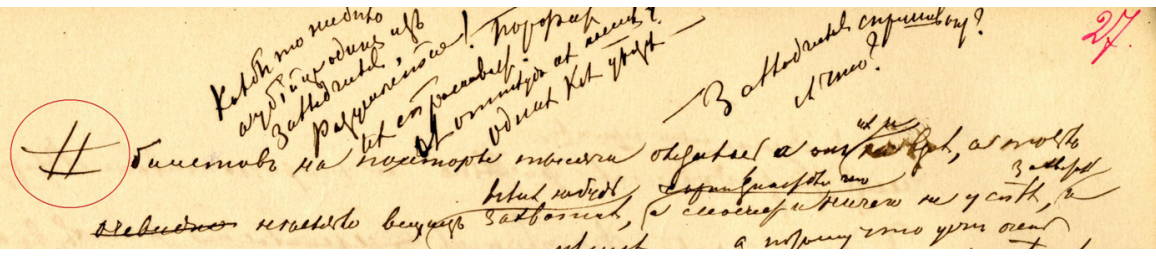

Илл. 2 
Таких примеров, когда части одного текста расположены на разных страницах и на отдалении друг от друга, достаточно много. Довольно многочисленны случаи соседствующего расположения связанных друг с другом записей на развороте или в пределах двух страниц, когда также затруднительно при публикации соблюсти принцип постраничного воспроизведения текста. Например, почти все поля с. 30-31 указанного чернового автографа заняты маргиналиями, которые связаны между собой, на что указывают авторские знаки (на илл. 3 это знаки $\left.\times_{1}, \times_{2}, \times_{3}, \times_{4}, \times_{5}\right)$ и соединительная линия, проведенная от заметок со с. 31 к записям на с. 30.

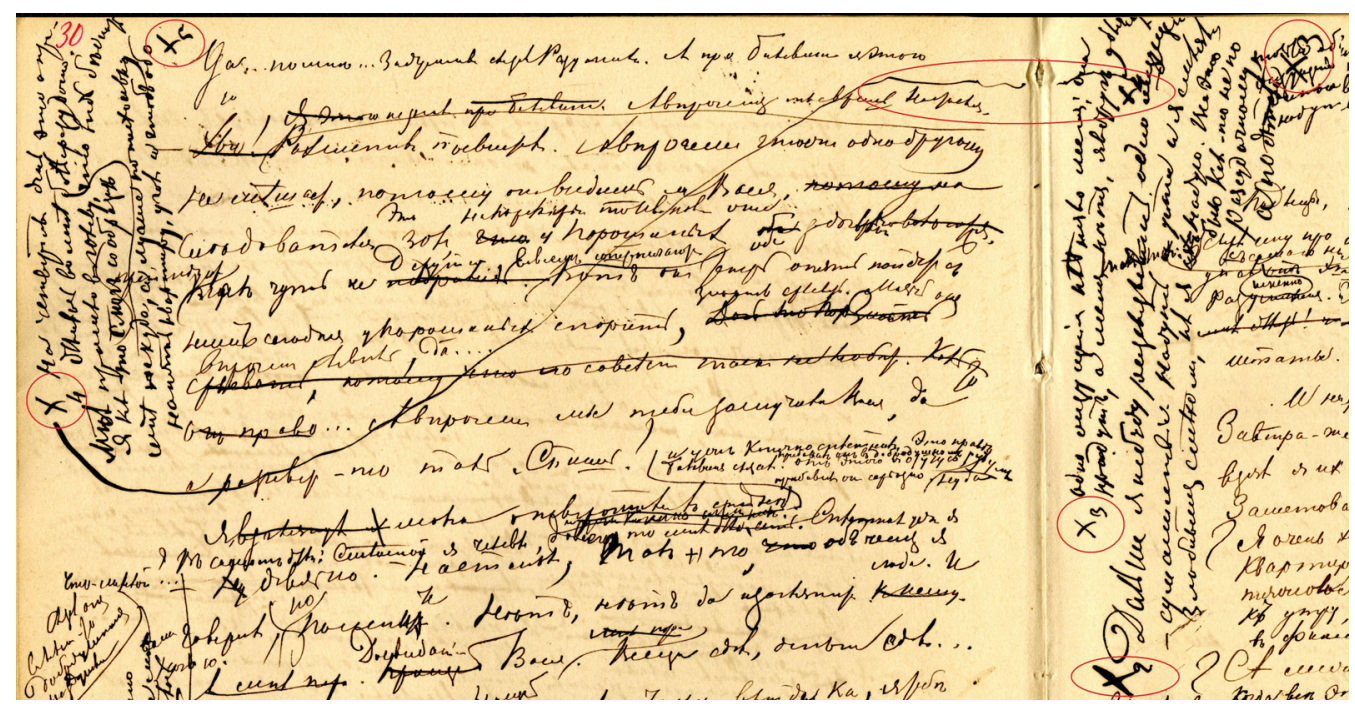

Илл. 3

Идея целостного отражения источника в печати важна применительно не только к наброскам, но и к черновому связному тексту. Черновые и беловые автографы Достоевского, наборные рукописи, корректуры его произведений напечатаны в академическом издании как свод вариантов текста. Выбор такой формы публикации имеет недостатки, которые особенно заметны, если вести речь о черновых автографах: во-первых, не всегда удобен поиск соответствий (или расхождений) между печатным текстом и отдельными вариантами; во-вторых, в самом процессе воспроизведения рукописи при такой 
отрывочной, искусственно фрагментарной, подаче материала неизбежно возникновение пропусков и ошибок чтения. Приходится говорить о том, что публикация рукописей в вариантах дает довольно слабое представление о первоисточнике, лишает читателей информации о расположении записей на рукописном листе, о характере маргиналий и вставок в основной текст. Когда слоев авторской правки в черновике много, а в печати эти слои перечисляются под литерами, читателю чрезвычайно трудно восстановить по этой информации картину, имеющуюся в рукописи.

Поясним высказанные мысли на примере из чернового автографа романа «Подросток». В рукописи (НИОР РГБ. Ф. 93.І.6/1. Л. 1, авторская нумерация - «Листъ 1») содержатся исправления - вычеркнутые и вписанные слова, а также маргиналии, которые автор отмечает специальными знаками, указывая на место набросков с полей в основной части текста:

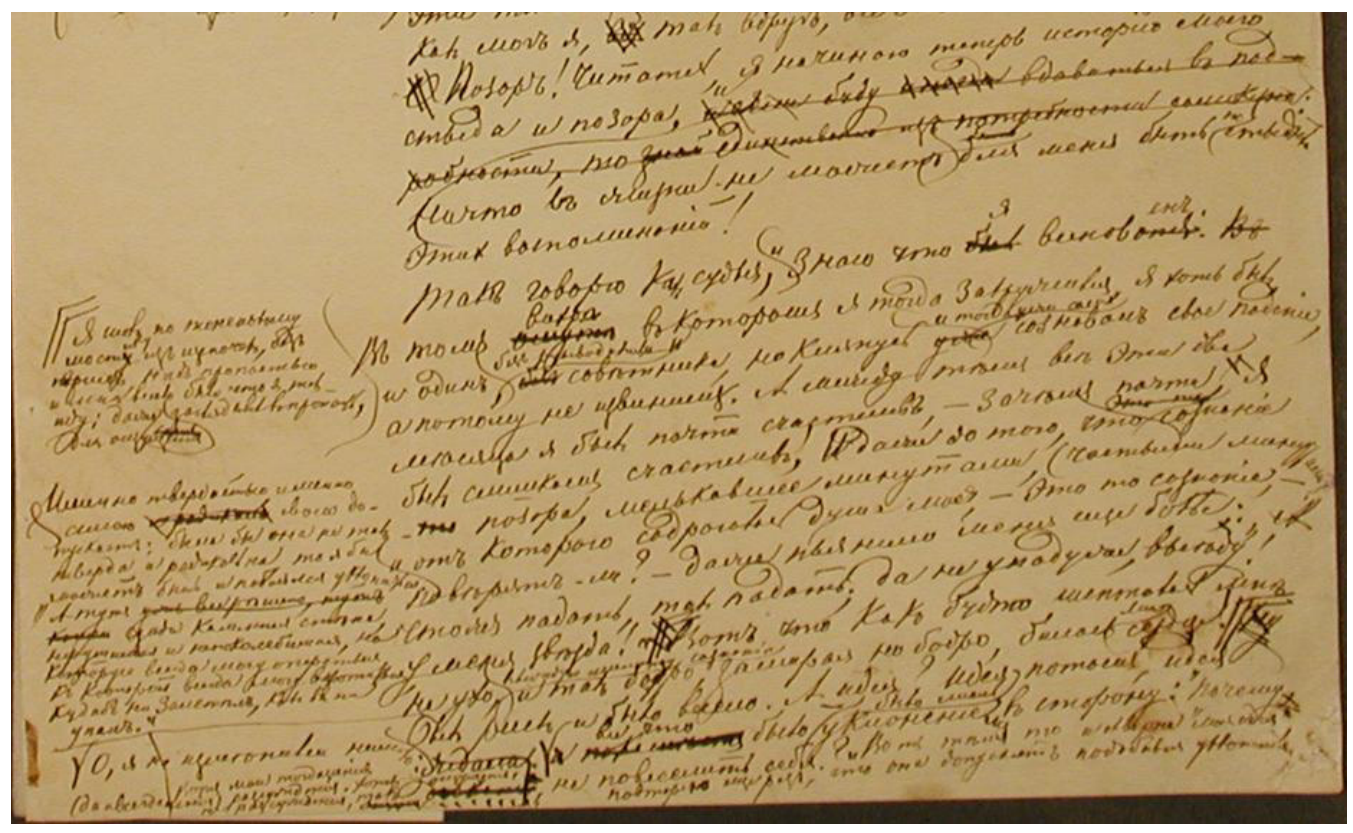

Илл. 4

В Д30 материал чернового автографа отражен в виде вариантов текста $(17,37,40)$ : 
2у-зи это - собственные $৩$ Позор! / a. Что же (О низость!), откуца у меня әти тысячи? С каков̆ стати я так жаву и зачем? Как мог я [вцр $\langle$ г $\rangle$ | так вдруг всё забыть и так изменигься? 0 nозор! 6. Эго тогдашние мои пзречения, о низость! Что же, откуда вдруг әти тысячи, әги рысаки " Борели? Как мог я так вдруг всё забыть и так измениться? Позор!

32 Ilocлe: моего стыда и позора - и если буду иногда вдаваться в подроб́ости, то знай, едшвственно пз потреб̆ности самокритики

32-зs не может $ง$ быть постыдне / не может для меня быть стыднее

म как $\sim$ внновен. / как судья и знаю, что был внноват.

34-36 В гом вихре $৩$ сознавал / В том омуте, в котором я тогда закружплся.

зз-зи Я хоть был и один, без совстника, но клянусь, уже сознавал.

3з-з" зачем почти? $৩$ позора / зачем почти, я был слишком счастлив и дажо

11 do того, что әто-то сознание-то позора

шьянило / даже пьянило

Cmp. 163-164.

\$2-1 Я шел s Был рпск / $а$. Вот что как будто шенгалось мн иа ухо, " так болро, замирая, но бодро билось сердце! Ну был риск. 6. Вот тто как бу:ато шенталось мне иа ухо в каждую минуту сознаншя. и так бодро, замирая, но бодро бнлось мие сердие! 9 шен ио гоненькиму мосту

пз тепочек, без перил. пад пропастью, п мпе весело было, что я так нду: даже заглядывал в цропасть в. пак в 6. далее: Я шел по тоненькому мостику из щеночек, без перил, над пропастью, и мне весело бы.ло, что я так нду: даже [cas] для ощущения заглядынал в пропасть $\diamond$

Cmp. 164.

r всё, что было $৩$ побоялся уклониться. / а. О, я не изменился нимало; вот мон тогдашине (да и всегдашнше) рассужпсиня. Хоть не рассул:дения, так опущения, а покамест всё, что было, - уклонение в сторону: "Почему, дескать, не повеселить ссб́я?" Вот тем-то и скверна моя идея, повторяю еще раз, что она допускает подобные уклонения. б. всё, что было, - было лишь уклоненшем в сторону: «Почему, дескать, не повеселить себя?» Вот тем-то и скверна моя идея,новторяю еще раз, что она допускает подобшые уклонения. Именно твердостью, именно сплою [и радикаль 〈ностью)] своею допускает; была бы она не так тверда и радикалын, то я бы, может быть, и побоялси уклоишться. А тут [уж всё решено. тут, кажет (ся)] сзади каменная стена, нерушимая и непоколеб́мая, на которую всегда могу онереться, к которой всегда могу возвратиться, куда б ни залетел, как бы пи упал.

\section{Илл. 5}

Проблема заключается в том, что публикация, построенная по такому принципу, не содержит целостного представления о тексте, а сами варианты, располагаемые под литерами, не всегда точно и понятно для читателя передают авторскую последовательность записей. Для сравнения приведем черновой текст автографа полностью, отражая ход творческого процесса при помощи знаков транскрипции ${ }^{6}$ 
...[O $n<0 з о р$ r $>]\{\Pi\}$ озорв! Читатель, я начинаю теперь исторію моего стьда и позора, [и если буду [иногда] <B Дзо слой правки не отражен. - 17, 37> вдаваться въ подробности, то [знай] <В Дзо слой правки не отражен. - 17, 37> единственно изб потребности самоказни $<$ В Д30 ошибочно: самокритики - 17, 37>] $\{u\}$ Ничто вг жизни не можеть [\{быть $\}]$ для меня быль \{по\}стьднпе этихъ воспоминаній!

Такъ говорю какъ судья, $\{u\}$ знаю<,> что [быль] $\{я\}$ винов $[a т ь]\{е н б\}$. $[$ Въ] <В Д30 пропуск. - 17, 37> Въ томг [омути] \{вихри\}, въ которомъ я тогда закружился, я хоть быль и одинб, \{безъ руководителя и\} [безб] совптника, но клянусь<,> [уже] $\{$ и тогда уже самь $\}$ сознаваль свое паденіе, а потому не извинимг. А между тпюкв всп эти два мпсяица я быль почти счастливб, - зачтмг почти[?]\{,\} $Я<B$ Д30 неточно: почти, я - 17, 37> быль слишкомъ счастливъ[,] $\{!\}[u]\{И\}$ даже до того, что [\{это-то\}] сознаніе [-то] позора, мелькавщее минутами, (частьми минутами!) $и<B$ Д30 пропуск. - 17, 37> отъ котораго содрогалась душа моя, - это-то сознаніе, - повпрять ли? - даже пьянило меня еще болье [,]\{:\} «А что жъ<,> падать, такъ падать; да не упаду же, выпду! У меня звпзда!» ${ }^{7}$ Воть что какъ будто шепталось мнпь на ухо, \{въ каждую минуту сознанія\} и такъ бодро, замирая<,> но бодро, билось \{мое сердие! $\{$ Я шоль по тоненькому мост $[y]\{u к y\}$ изъ щепочекъ, безб периль, надт пропастью, и мнть весело было<,> что я такъ иду: даже $[\{с а м ъ\}]$ заглядываль въ пропасть, для очущенія <B Д30 ошибочно: даже [сам] для ощущения заглядывал в пропасть. $-17,40>\}^{9}$. [Ну] Быль рискъ и было весело. А идея? Идея потомъ, идея ждала ${ }^{10}$. [О, я не измпнился нимало: Воть $<$ В Д30 ошибочно: нимало; вот -17 , 40> мои тогдашнія (да и всегдашнія) разсужденія. Хоть не разсужденія,

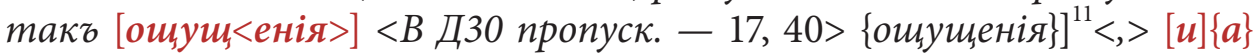
$<$ В Д30 слой правки не отражен. - 17, 40> [покампсть] $\{в с е<,>$ что $\}$

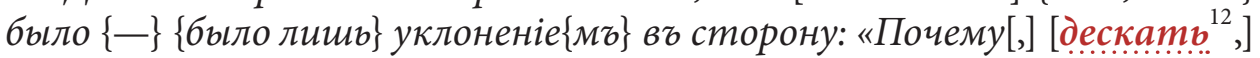
$<$ В ДЗ характер правки (вычеркнуто и восстановлено) не отражен. 17, 40> не повеселить себя?» Воть тпмъ-то и скверна «моя идея» $<$ Д Д30 пропуск кавычек: моя идея $-17,40>$, повторяю еще разб, что она допускаеть подобныя уклоненія. ${ }^{13}$ \{Именно твердостью, именно силою [и радикаль<ностью>] своею допускаетъ: была $<$ ДЗ До ошибочно: допускает; была - 17, 40> бы она не такъ тверда и радикальна, то я бы<,> можеть быть<,> и побоялся уклониться. «А туть [ужь все ргшено, туть камен<ная > <B Д30 ошибочно: кажет<ся> - 17, 40>] сзади каменная стпна, нерушимая и непоколебимая, на которую всегда могу опереться, къ которой всегда могу воротиться $<B$ ДЗО ошибочно: возвратиться - 17, 40>, куда бъ ни залетпль, какъ бъ ни упалъ»\}. 
Полнотекстовое воспроизведение автографа дает больше информации, позволяя публикатору показать взаимосвязь записей, наличие в рукописи помет и условных обозначений, процесс возникновения слоев текста в результате авторской правки. Описанный подход, кроме того, облегчает читателю (исследователю) сам процесс сравнительного анализа опубликованного рукописного источника и печатного (основного) текста: сопоставлять два полных текста, в которых отражена вся необходимая информация, значительно удобнее, чем сравнивать печатный текст с фрагментами чернового, представленными вне их контекстуальных связей.

При сверке указанной рукописи и ее академической публикации были выявлены ошибки: в отдельных случаях, помимо неверного прочтения слов и пунктуации, пропущена информация о выполненной Достоевским правке. При этом обнаруживается еще одна проблема (которая проявляется не только на примере данной рукописи, но и во многих других случаях на разнотекстовом материале): предлагаемые публикаторами варианты автографа имеют интерпретационный характер и не всегда точны. В частности, в указанном выше отрывке публикации выделены такие варианты:

a. Вот что как будто шепталось мне на ухо, и так бодро, замирая, но бодро, билось сердце! Ну был риск. б. Вот что как будто шепталось мне на ухо в каждую минуту сознания, и так бодро, замирая, но бодро, билось мое сердце!...

Под литерой $а$ приводится то, что отнесено к первому слою записи, под 6 - ко второму. Обе вставки Достоевского в текст - «в каждую минуту сознания» и «мое» - признаются, таким образом, одновременно возникшими. Однако при чтении автографа возможны и другие варианты:

- без вставки «мое»: «Вотъ что какъ будто шепталось мнъ на ухо, \{въ каждую минуту сознанія\} и такъ бодро, замирая<,> но бодро, билось сердце!»

- без вставки «въ каждую минуту сознанія»: «Вотъ что какъ будто шепталось мнъ на ухо, и такъ бодро, замирая<,> но бодро, билось \{мое\} сердце!» 
Здесь приведен «простой» случай авторской правки рукописи, когда в пределах предложения или более широкого контекста появляются два исправления, сделанные автором. При более сложных и многочисленных исправлениях такие «умозрительные» варианты, основанные на гипотетическом выделении слоев записи, также увеличиваются в числе, а их перечень под литерами существенно затрудняет читательское представление о первоисточнике и понимание опубликованного текста.

Не все произведения писателя представлены материалами, отражающими этап связного чернового текста: так, к роману «Идиот», в отличие от «Подростка», сохранились только черновые наброски в записных тетрадях Достоевского. Соответственно, в данном случае вопрос о вариантах чернового и белового автографов не стоит. Но сохраняют свое значение вопросы, связанные с исследованием порядка записей и определением последовательности творческого процесса. На этой стадии авторской работы текст может иметь незавершенный, отрывочный характер, или, будучи связным, сопровождаться лаконичными пометами, типичными именно для черновых набросков. Приведем пример из рабочей тетради с записями к роману «Идиот» (РГАЛИ. Ф. 212.1.5. С. 37), используя транскрипционную подачу материала, позволяющую показать характер авторской правки.

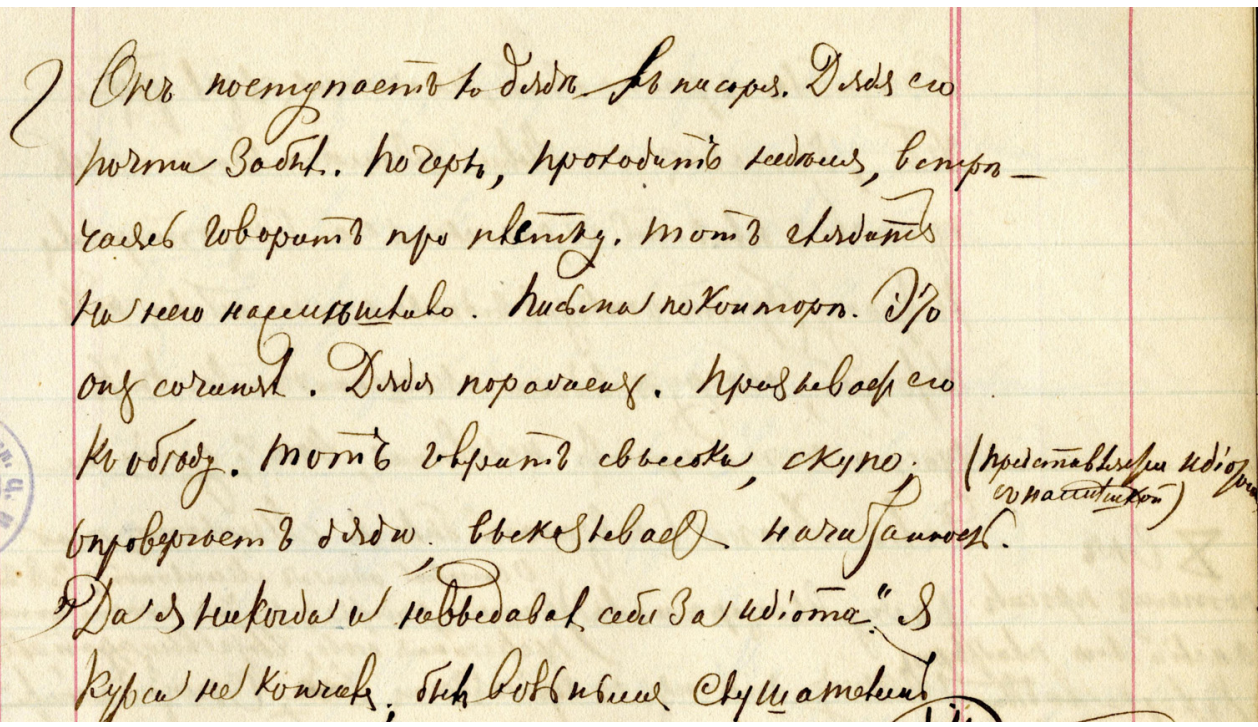


$Z^{15}$ Онъ поступаетъ къ дядю[. В]\{в\}б писаря. Дядя его почти забылъ. Почеркъ, проходить недюля, встргчаясь говорить про плетку. Тоть глядить на него насмпшливо. Письма по конторг. Это онъ сочиняль. Дядя пораженъ. Призываетъ его къ обюду. Тотъ говоритъ свысока, скупо; опровергаеть дядю; выказываеть начитанность ${ }^{16}$. "Да я никогда и не выдаваль себя за идіота.» Я курса не кончиль; быль вольнымъ слушателемъ.

На полях против текста: «Тоть говорить свысока выказываеть начитанность» - сделана запись: «(Представляется идіотомъ, съ насмпикой)». В Д30 набросок вставлен двумя строками выше - видимо, по причине лексического и смыслового сходства двух предложений: «Тот глядит на него насмешливо. (Представляется идиотом, с насмешкой)» $(9,143)$. Это пример исследовательской интерпретации, которая не находит подтверждения в автографе: вписанный фрагмент расположен в другом месте, с основным текстом он не связан никакими авторскими пометами, поля страницы при этом свободны и при желании автор мог поместить (но не сделал этого) запись выше - напротив указанного предложения. По форме набросок похож на маргиналии, которые выполняют функцию пояснения, будучи содержательно связанными или со всем абзацем, или с текстом, напротив которого находятся. В данном случае вероятна связь маргиналии с кратко описанной в этом черновом плане сценой обеда у Дяди, где главный герой одновременно и «представляется идиотом, с насмешкой», и опровергает это представление («говорит свысока», «опровергает дядю», «выказывает начитанность», «Да я никогда и не выдаваль себя за идиота»). В некоторой степени этот эпизод напоминает сцены окончательного текста романа, когда князь Мышкин знакомится с генералом Епанчиным и его семейством, произведя похожее двойственное впечатление ${ }^{17}$, однако, в отличие от героя набросков, в поведении князя не проявляются такие качества, как насмешливость и высокомерие.

Полнотекстовые версии рукописей могут оформляться по-разному: во-первых, как показано в примерах выше, с помощью транскрипции, во-вторых, посредством выделения последнего слоя записи (или признанного таковым публикаторами) и приведения остальных слоев текста в подстрочных примечаниях, содержащих, кроме того, необходимые редакционные пояснения (второй метод последовательно 
используется в Д30). Если сравнивать эти подходы, то первый - транскрипционный - иногда сложен для восприятия, но точнее передает ход творческого процесса автора; второй подход эстетичнее, но содержит больше условий для произвольной интерпретации рукописного текста и неточной его передачи.

Разработка транскрипции полезна именно в исследовательских целях, так как транскрибирование позволяет фиксировать детали прочтения рукописи и характер передачи текстологических фактов ${ }^{18}$. Система транскрипционного описания может усложняться в зависимости от того, какой объем информации публикатор намерен с ее помощью отразить: только исправления чернового автографа; правку и корректурные варианты; правку и варианты окончательного текста. То же самое следует сказать и о публикации белового текста, а также корректуры и авторских помет на гранках.

Определяя транскрипцию как рабочий инструмент текстолога при подготовке рукописного текста к печати, не следует, однако, абсолютизировать ее роль в воспроизведении рукописей, чтобы транскрипционный подход не усложнял читательское восприятие материала. Набор знаков текстологической нотации должен быть минимален и прост: например, использование скобок разных типов для вычеркнутого и вписанного автором текста, а также для редакционных помет. Было бы неуместно превращать авторский текст в шифровку, недоступную пониманию исследователей или становящуюся самостоятельным объектом изучения, уводящим исследовательское внимание от содержания публикуемого материала. В Д30 есть элементы простого, не затрудняющего внимание транскрипционного описания, которые используются при отражении вариантов черновых и беловых автографов Достоевского, - прежде всего, это квадратные скобки для обозначения вычеркнутого текста. Однако этих знаков транскрипции не всегда достаточно для передачи информации о первоисточнике.

Если не применять транскрипционный подход (в Д30 по отношению к черновым наброскам он не применяется), то необходимо подробное словесное описание информации о расположении записей на листе и их взаимосвязи. Такой метод применен в издании рукописей «Братьев Карамазовых» под редакцией А. С. Долинина [21] ${ }^{19}$, в котором даны не только подробнейшие характеристики рукописного текста, но и показаны многие условные обозначения (знаки Достоевского), находящиеся на полях рукописи. В публикациях рукописного текста 
знаки Достоевского почти не воспроизводятся. В немецком издании рукописей «Братьев Карамазовых», подготовленном В. Л. Комаровичем [24], условные знаки Достоевского воспроизводятся менее последовательно, чем у Долинина, некоторые авторские обозначения опускаются. Кроме того, публикация Долинина, по сравнению с немецким вариантом, является более полной, о чем говорит сам издатель: «Материалы из Публичной библиотеки им. Ленина, В. Л. Комаровичем не воспроизведенные и не изученные <...> целиком вошедшие в наш свод, были для меня здесь особенно надежной опорой. Записи, сохранившиеся в ИРЛИ, ими не только восполняются, а получают сплошь и рядом совершенно новое освещение» [21, 348].

Сравнение академического (Д30) и более ранних изданий рукописей обнаруживает, что в первых публикациях чаще более точно воспроизводятся орфографические характеристики авторского текста, но при этом больше смысловых (лексических) ошибок чтения. В Д30 многие ошибки первых изданий исправлены, но при этом происходит модернизация языковых характеристик рукописи.

Следующий пример из публикации черновиков романа «Братья Карамазовы» (НИОР РГБ. Ф. 93. І.2.1/19. С. 8) показывает, как видоизменяется текст в зависимости от установок издателей, в том числе интерпретационных:

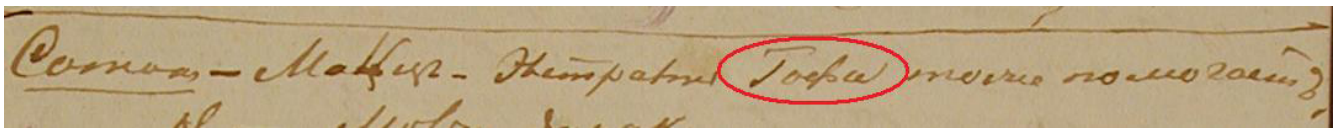

Илл. 7

Рукопись: «Сатана - Мальць-Экстракть Гофа тоже помогаетъ». Долинин: Гоф<ман>а (283).

Д30: Гоффа $(7,322)$.

В Долинин содержится неточная интерпретация автографа: несмотря на то, что в рукописи отчетливо записана фамилия Гоффа, слово прочитано с расшифровкой «Гоф<ман>а». Верное прочтение предложено в Д30 (с изменением орфографического облика записи: «Гоффа» вместо «Гофа»). Установлено, что Гофф - реальное лицо, коммерсант, придворный поставщик популярных в тот период целительных средств: «Как раз во время работы Достоевского над IX главой одиннадцатой книги романа на страницах “Нового времени” проводилась рекламная 
кампания целительных “мальц-экстрактовых” средств коммерции советника, “поставщика Двора” Иоганна Гоффа (коммерции советник Гофф - почти персонаж Гофмана!). Это были не обычные объявления, а письма “исцеленных", вслед за которыми ненавязчиво сообщался адрес склада и цены на препараты (стратегия, до сих пор применяемая в соответствующем бизнесе)» [19, 272].

Исследование рукописей Достоевского приводит к выводу о том, что записные тетради - самые сложные по составу и форме источники. Сложность заключается в том, что привлекательная идея их аутентичной публикации, то есть без перестановки записей согласно интерпретации исследователя-публикатора и с точным сохранением текста в пределах каждой страницы, затруднена особенностями самого творческого процесса Достоевского. На одной странице тетради нередко оказываются не просто независимые друг от друга записи к разным произведениям, но и одновременно - связанные с текстом, находящимся на других, иногда вовсе не соседних, страницах. Такие связи не только могут быть тематическими, смысловыми, возникающими в сознании исследователя, но и иметь прямые авторские указания на этот счет (знаки соединения записей). И тогда решение публиковать каждую страницу, не учитывая последовательность заполнения всей тетради и особенности авторского обдумывания записей (возвращения к ним, уточнения их взаимосвязей посредством знаков и помет), будет вызывать вопросы. В таком случае, при установке на «аутентичное» воспроизведение источника постранично, потребуются подробные комментарии, разъясняющие ход творческого процесса автора. Подстрочный комментарий будет по преимуществу текстологическим; затекстовый, как и принято в научных изданиях, - текстологическим, историко-литературным и реальным.

Еще один трудноразрешимый вопрос: как поступать, если записная тетрадь содержит материалы к нескольким разновременным произведениям (например, к романам и незавершенным замыслам Достоевского)? Можно было бы печатать записные тетради блоком - в специальных томах издания, для этого предназначенных. Но, учитывая небыстрые сроки выхода томов, включающих материалы к нескольким крупным произведениям, публикация записных тетрадей по такому принципу затруднила бы путь читателя к отдельным интересующим 
его текстам и нарушила бы хронологию представления рукописей Достоевского в печати. Этот вопрос остается открытым.

Обращает на себя внимание и проблема публикации незавершенных замыслов Достоевского второй половины 1860-х - начала 1870 -х годов $^{20}$. В случае «аутентичного» воспроизведения текста записных тетрадей эти наброски не должны вычленяться из общего корпуса текстов каждой тетради. Но возможен и другой вариант, мотивированный в частности тем, что такие заметки, как правило, занимают отдельные страницы, что указывает на их относительную самостоятельность, отделенность от других записей, - помещение их в специальные тематические разделы согласно хронологии появления. В Д30 такие наброски распределены по разным томам, в соответствии с датировками, которые в большинстве случаев предположительны (когда нет авторских дат в рукописи) и не всегда получают достаточную аргументацию. Более обоснованным текстологическим решением была бы публикация всех таких записей, датируемых 1866-1872 годами, в общем разделе в одном томе, так как они содержат сквозные темы и образы, имеющие значение для всего творчества писателя, как более раннего, так и позднейшего. Это важно и потому, что попытки привязать подобного рода наброски к какому-то одному произведению могут привести к искаженному представлению о творческой истории художественных замыслов автора.

В настоящее время перед исследователями стоят задачи определения современных подходов к публикации рукописного текста и отражения всего хода творческого процесса Достоевского, с учетом особенностей графики, каллиграфии, рисунков писателя. Разные по характеру записи (деловые, описание припадков, расчеты) обычно либо вообще опускаются при публикации, либо печатаются отдельно, и это тоже проблема, которую необходимо рассматривать при подготовке научного издания рукописей, так как пропуск информации такого рода не всегда позволяет представить текст как целое, не говоря уже о восстановлении хронологии его создания ${ }^{21}$. Необходимо также учитывать, что проблематика, связанная с материалами к каждому отдельному произведению, индивидуальна, и при рассмотрении многих текстологических вопросов не всегда возможно и необходимо применение унифицирующих подходов: у каждого текста своя история, материал зачастую подсказывает исследовательские решения. 


\section{ПРИМЕЧАНИЯ}

"Исследование выполнено при финансовой поддержке РГНФ, проект № 15-0400130a.

1 См. подробнее: [16, 119-129, 332-363].

2 Сходные мысли высказал Г. И. Чулков: «...за невозможностью установить точную хронологию записей, лучше публиковать документ в том виде, в каком он обозревается теперь, не тасуя произвольно текстов и не исключая ничего “лишнего"» $[23,162]$.

3 Далее - Д30; ссылки на это издание приводятся в тексте статьи с указанием тома и страницы в круглых скобках.

4 Л. М. Розенблюм, говоря о принципе «тематического разделения материалов записных книжек Достоевского», подчеркнула, что в таком издании «записи лишаются той “естественной среды”, в которой они возникли и которая небезразлична для их понимания» $[14,92]$. См. также: $[3,52-53] ;[11,80]$.

5 Такая работа проводится в научных коллективах российских архивов, библиотек и музеев, в частности в РГАЛИ, РО ИРЛИ, НИОР РГБ, ГЛМ и др. См., напр.: [1].

6 В квадратных скобках приводится вычеркнутый Достоевским текст, в фигурных скобках - вписанный.

7 Далее вписан и вычеркнут знак вставки 1.

8 Далее вписан знак вставки 1.

9 Вписано слева на полях под знаком вставки 1.

10 Далее вписан знак вставки 2.

11 Вписано слева на полях под знаком вставки 2.

12 Пунктир означает, что автор восстановил вычеркнутое.

13 Далее вписан знак вставки 3 (в рукописи край страницы истерся, и знак слабо виден).

14 Вписано слева на полях под знаком вставки 3.

15 Знак абзаца.

16 На полях справа запись: (Представляется идіотомъ, съ насмюшкой).

17 Ср.: «Частые припадки его болезни сделали из него совсем почти идиота (князь так и сказал “идиота”)» $(8,25) ;$ «Генеральша была ревнива к своему происхождению. Каково же ей было, прямо и без приготовления, услышать, что этот последний в роде князь Мышкин, о котором она уже что-то слышала, не больше как жалкий идиот и почти что нищий и принимает подаяние на бедность. Генерал именно бил на эффект, чтобы разом заинтересовать, отвлечь всё как-нибудь в другую сторону» $(8,44)$; «- Дайте же ему по крайней мере, maman, говорить, - остановила ее Александра. - Этот князь, может быть, большой плут, а вовсе не идиот, - шепнула она Аглае» $(8,48)$, и др.

18 См. подробнее: [13].

19 Далее - Долинин; ссылки на это издание приводятся в тексте статьи с указанием страницы в круглых скобках.

20 См. подробнее: [17].

21 См.: [18]. 


\section{СПИСОК ЛИТЕРАТУРЫ}

1. Актуальные проблемы источниковедения и текстологии в контексте современных информационных технологий : материалы Всероссийской научной конференции, посвященной 100-летию со дня основания Государственного музея Л. Н. Толстого (1911-2011). - Москва : Государственный музей Л. Н. Толстого, 2011. - $206 \mathrm{c}$.

2. Бродский, Н. Л. [Рецензия на книгу] Творчество Достоевского 1821-1881-1921 г. Сборник статей и материалов под редакцией Л. П. Гроссмана. Всеукраинское Государственное Издательство. Одесса, 1921. 150 стр. / Н. Л. Бродский // Красный архив. - 1922. - Т. 1. - С. 435-438.

3. Великанова, Н. П. Воля и неволя автора «Войны и мира» (издание рукописей и основного текста) / Н. П. Великанова // Проблемы текстологии и эдиционной практики. Опыт французских и российских исследователей / под ред. М. Делона и Е. Дмитриевой. - Москва : ОГИ, 2003. - С. 51-63.

4. Достоевский, Ф. М. Полное собрание сочинений : в 30 т. / Ф. М. Достоевский. Ленинград : Наука, 1972-1990.

5. Достоевский, Ф. М. Полное собрание сочинений и писем : в 35 т. / Ф. М. Достоевский / ИРЛИ (Пушкинский Дом) РАН. - Т. 1-4. - Санкт-Петербург : Наука, 2013-2016-.

6. Достоевский, Ф. М. Полное собрание сочинений : канонические тексты : [в 15 т.] / Ф. М. Достоевский / под ред. В. Н. Захарова. - Т. 1-9, 11. - Петрозаводск : Издво ПетрГУ, 1995-2015-.

7. Записные тетради Ф. М. Достоевского / подг. к печати Е. Н. Коншиной ; комм. Н. И. Игнатовой и Е. Н. Коншиной. - Москва ; Ленинград : ACADEMIA, 1935. $-475 \mathrm{c}$.

8. Из архива Ф. М. Достоевского. Идиот. Неизданные материалы / Центрархив ; под ред. П. Н. Сакулина и Н. Ф. Бельчикова. - Москва ; Ленинград : ГИХЛ, 1931. $-320 \mathrm{c}$.

9. Из архива Ф. М. Достоевского. Преступление и наказание. Неизданные материалы / Центрархив ; подг. к печати И. И. Гливенко. - Москва ; Ленинград : ГИХЛ, 1931. - 219 с.

10. Комарович, В. Л. Литературное наследство Достоевского за годы революции. Обзор публикаций 1917-1933 гг. / В. Л. Комарович. - Москва : Журнально-газетное объединение, 1934. - С. 258-281. - (Серия «Литературное наследство» ; T. 15).

11. Лощинская, Н. В. О своеобразии текстологической проблематики академического издания лирики А. А. Блока (к постановке вопроса) / Н. В. Лощинская // Русский модернизм : проблемы текстологии / отв. ред. О. А. Кузнецова. - СанктПетербург : Алетейя, 2001. - С. 73-91.

12.Неизданный Достоевский. Записные книжки и тетради 1860-1881 гг. / АН СССР; Институт мировой литературы им. А. М. Горького ; ред. И. С. Зильберштейн, Л. М. Розенблюм. - Москва : Наука, 1971. - 728 с. - (Серия «Литературное наследство» ; Т. 83). 
13. Перцов, Н. В. Об аутентичном факсимильно-транскрипционном представлении рукописей русских классиков / Н. В. Перцов // Филологические науки. - 2015. № 1. - С. 75-94.

14. Розенблюм, Л. М. Проблемы публикации записных книжек писателя (из опыта «Литературного наследства») / Л. М. Розенблюм // Современная текстология : теория и практика / ИМЛИ им. А. М. Горького РАН. - Москва : Наследие, 1997. - С. 89-94.

15. Розенблюм, Л. М. Творческие дневники Достоевского / Л. М. Розенблюм. Москва : Наука, 1981. - 368 с.

16. Тарасова, Н. А. «Дневник писателя» Ф. М. Достоевского (1876-1877) : критика текста. - Москва : Квадрига, МБА, 2011. - 392 с.

17. Тарасова, Н. А. Проблемы публикации и комментирования незавершенных замыслов Достоевского конца 1860-х - начала 1870-х годов / Н. А. Тарасова // Неизвестный Достоевский [Электронный ресурс] : международный научный журнал. - 2016. — № 3. - С. 70-91. — URL : http://unknown-dostoevsky.ru/files/ redaktor_pdf/1477998652.pdf (7.11.2016).

18. Тарасова, Н. А., Панюкова, Т. В. Графика - семантика - фактография : проблемы текстологии записных тетрадей Достоевского / Н. А. Тарасова, Т. В. Панюкова // Неизвестный Достоевский [Электронный ресурс] : международный научный журнал. — 2016. — № 4. - C. 23-46. — URL : http://unknown-dostoevsky. ru/files/redaktor_pdf/1481719297.pdf (14.12.2016).

19. Фетисенко, О. Л. Граф Маттеи и коммерции советник Гофф. «Братья Карамазовы». Дополнение к комментариям / О. Л. Фетисенко // Достоевский. Материалы и исследования. - Т. 17. - Санкт-Петербург : Наука, 2005. - С. 269-274.

20.Ф. М. Достоевский в работе над романом «Подросток». Творческие рукописи / АН СССР ; Институт мировой литературы им. А. М. Горького ; [подгот. текста А. С. Долинина] ; ред. И. С. Зильберштейн, Л. М. Розенблюм. - Москва : Наука, 1965. - 520 с. - (Серия «Литературное наследство»; Т. 77).

21. Ф. М. Достоевский. Материалы и исследования / АН СССР ; Институт русской литературы ; под ред. А. С. Долинина. — Ленинград : Изд-во АН СССР, 1935. $603 \mathrm{c}$.

22.Ф. М. Достоевский. Преступление и наказание / АН СССР ; изд. подгот. Л. Д. Опульская и Г. Ф. Коган. - Москва : Наука, 1970. — 809 с. - (Серия «Литературные памятники»).

23. Чулков, Г. И. Как работал Достоевский / Г. И. Чулков. - Москва : Сов. писатель, 1939. - 339 c.

24.F. M. Dostojewski. Die Urgestalt der Brüder Karamasoff. Dostojewskis Quellen, Entwürfe und Fragmente, erläutert von W. Komarowitsch. - München : R. Piper, 1928. $-619 \mathrm{~s}$. 
Natalia A. Tarasova

Doctor of Philology, Leading Researcher of the Institute of Russian Literature (Pushkinskiy Dom),

Russian Academy of Sciences,

(Saint Petersburg, Russian Federation)

nsova74@mail.ru

\title{
THE PROBLEMS OF THE PUBLICATION \\ OF DOSTOEVSKY'S MANUSCRIPTS \\ (based on draft manuscripts)
}

\begin{abstract}
The article is devoted to the textual analysis and publication of Dostoyevsky's draft manuscripts, more specifically sketches in his notebooks and coherent draft texts. The presented results cover the manuscripts created between 1865 and 1879, such as drafts of the novels "Crime and Punishment", "The Idiot", "The Adolescent", and "The Brothers Karamazov". The Article also considers in detail scientific approaches to the publication of Dostoevsky's creative heritage evolved in the 1920s-1930s and developed later, into the scientific concept of academic edition of the author's works. Based on this analysis, the range of issues is determined, important for modern Dostoevsky studies and for new projects related to the publication of Dostoevsky's texts, both paper and electronic books.
\end{abstract}

Keywords: Dostoevsky, textual criticism, draft manuscripts, publishing practice

\section{REFERENCES}

1. Aktual'nye problemy istochnikovedeniya i tekstologii v kontekste sovremennykh informatsionnykh tekhnologiy: materialy Vserossiyskoy nauchnoy konferentsii, posvyashchennoy 100-letiyu so dnya osnovaniya Gosudarstvennogo muzeya L. N. Tolstogo (1911-2011) [Current Issues of Source Studies and Textual Criticism from the Perspective of Modern Information Technologies: Proceedings of Russian Scientific Conference on the 100th Anniversary of the L. N. Tosltoy State Museum (1911-2011)]. Moscow, The State Museum of Leo Tolstoy Publ., 2011. 206 p.

2. Brodskiy N. L. Retsenziya na knigu Tvorchestvo Dostoevskogo 1821-1881-1921 g. Sbornik statey i materialov pod redaktsiey L. P. Grossmana. Vseukrainskoe Gosudarstvennoe Izdatel'stvo. Odessa, 1921. 150 s.» [Book Review on “Dostoevsky's Creative Work During the Years 1821-1881-1921. The Collected Frticles and Materials Edited by L. P. Grossman. Ukrainian State Publishing House. Odessa, 1921. 150 p.”]. Krasnyy arkhiv, 1922, vol. 1, pp. 435-438.

3. Velikanova N. P. Volya i nevolya avtora «Voyny i mira» (izdanie rukopisey i osnovnogo teksta) [Free Will and Necessity of the Author of "War and Peace"]. Problemy tekstologii $i$ editsionnoy praktiki. Opyt frantsuzskikh i rossiyskikh issledovateley [Textual and Editorial Issues. The Experience of French and Russian Researchers]. Moscow, United Humanitarian Publishing House, 2003, pp. 51-63.

4. Dostoevskiy F. M. Polnoe sobranie sochineniy: $v 30$ tomakh [The Complete Works: in 30 Vols]. Leningrad, Nauka Publ., 1972-1990. 
5. Dostoevskiy F. M. Polnoe sobranie sochineniy i pisem: $v 35$ tomakh [The Complete Works and Letters: in 35 Vols]. St. Petersburg, Nauka Publ., 2013-2016-., vol. 1-4.

6. Dostoevskiy F. M. Polnoe sobranie sochineniy: kanonicheskie teksty: $v 15$ tomakh [The Complete Works: Canonical Texts: in 15 Vols]. Petrozavodsk, Petrozavodsk State University Publ., 1995-2015-., vol. 1-9. 11.

7. Zapisnye tetradi F. M. Dostoevskogo [Notebooks of Fyodor Dostoevsky]. Moscow, Leningrad, ACADEMIA Publ., 1935. 475 p.

8. Iz arkhiva F. M. Dostoevskogo. Idiot. Neizdannye materialy [Fyodor Dostoevsky's Archive. The Idiot. Unpublished Materials]. Moscow, Leningrad, Gosudarstvennoe izdatel'stvo khudozhestvennoy literatury Publ., 1931. 320 p.

9. Iz arkhiva F. M. Dostoevskogo. Prestuplenie i nakazanie. Neizdannye materialy [Fyodor Dostoevsky's Archive. Crime and Punishment. Unpublished Materials]. Moscow, Leningrad, Gosudarstvennoe izdatel'stvo khudozhestvennoy literatury Publ., 1931. 219 p.

10. Komarovich V. L. Literaturnoe nasledstvo Dostoevskogo za gody revolyutsii. Obzor publikatsiy 1917-1933 gg. [Dostoevsky's Literary Heritage in the Years of Revolution. Overview of the Publications of 1917-1933]. Moscow, Zhurnal'no-gazetnoe ob»edinenie Publ., 1934, vol. 15, pp. 258-281.

11. Loshchinskaya N. V. O svoeobrazii tekstologicheskoy problematiki akademicheskogo izdaniya liriki A. A. Bloka (k postanovke voprosa) [On the Specifics of Textual Problems of the Academy Publication of A. A. Blok's lyrics (Problem Setting)]. Russkiy modernizm: problemy tekstologii [Russian Modernism: Problems of Textual Criticism]. St. Petersburg, Aleteyya Publ., 2001, pp. 73-91.

12. Neizdannyy Dostoevskiy. Zapisnye knizhki i tetradi 1860-1881 gg. [Unpublished Dostoevsky. Sketchbooks and Notebooks of 1860-1881]. Moscow, Nauka Publ., 1971, vol. 83.728 p.

13. Pertsov N. V. Ob autentichnom faksimil'no-transkriptsionnom predstavlenii rukopisey russkikh klassikov [On the Authentic Facsimile-Transcriptional Presentation of the Manuscripts of Russian Classics]. Filologicheskie nauki [Philological Sciences. Scientific Essays of Higher Education], 2015, no. 1, pp. 75-94.

14. Rozenblyum L. M. Problemy publikatsii zapisnykh knizhek pisatelya (iz opyta «Literaturnogo nasledstva») [The Problems of Publishing the Writer's Notebooks (based on the Experience of "Literary Heritage")]. Sovremennaya tekstologiya: teoriya i praktika [Modern Textual Criticism: Theory and Practice]. Moscow, Nasledie Publ., 1997, pp. 89-94.

15. Rozenblyum L. M. Tvorcheskie dnevniki Dostoevskogo [Fyodor Dostoevsky's Artistic Diaries]. Moscow, Nauka Publ., 1981. 368 p.

16. Tarasova N. A. "Dnevnik pisatelya» F. M. Dostoevskogo (1876-1877): kritika teksta [“A Writer's Diary” by Fyodor Dostoevsky (1876-1877): Textual Criticism: Monograph]. Moscow, Quadriga; MBA Publ., 2011. 392 p.

17. Tarasova N. A. Problemy publikatsii i kommentirovaniya nezavershennykh zamyslov Dostoevskogo kontsa 1860-kh - nachala 1870-kh godov [The Issues of Publishing and Commenting on Unrealized Ideas of Dostoevsky in the Late 1860s and Early 1870s]. Neizvestnyy Dostoevskiy. Mezhdunarodnyy nauchnyy zhurnal [The Unknown 
Dostoevsky: International Research Journal], 2016, no. 3, pp. 70-91. Available at: http://unknown-dostoevsky.ru/files/redaktor_pdf/1477998652.pdf (accessed 07 November 2016).

18. Tarasova N. A., Panyukova T. V. Grafika - semantika - faktografiya: problemy tekstologii zapisnykh tetradey Dostoevskogo [Graphics - Semantics - Factography: Textual Problems of Dostoevsky's Notebooks]. Neizvestnyy Dostoevskiy. Mezhdunarodnyy nauchnyy zhurnal [The Unknown Dostoevsky: International Research Journal], 2016, no. 4, pp. 23-46. Available at: http://unknown-dostoevsky.ru/files/redaktor_pdf/1481719297. pdf (accessed 12 December 2016).

19. Fetisenko O. L. Graf Mattei i kommertsii sovetnik Goff. «Brat'ya Karamazovy». Dopolnenie k kommentariyam [Count Mattei and Trade Adviser Goff. "The Brothers Karamazov". Supplements to Commentaries]. Dostoevskiy. Materialy i issledovaniya [Dostoevsky. Materials and Researches]. St. Petersburg, Nauka Publ., 2005, vol. 17, pp. 269-274.

20. F. M. Dostoevskiy v rabote nad romanom «Podrostok». Tvorcheskie rukopisi [Fyodor Dostoevsky During his Work on the Novel "The Adolescent". Artistic Manuscripts]. Moscow, Nauka Publ., 1965, vol. 77. 520 p.

21. F. M. Dostoevskiy. Materialy i issledovaniya [Fyodor Dostoevsky. Materials and Researches]. Leningrad, Academy of Sciences of the USSR Publ., 1935. 603 p.

22. F. M. Dostoevskiy. Prestuplenie i nakazanie [Fyodor Dostoevsky. Crime and Punishment]. Moscow, Nauka Publ., 1970. 809 p.

23. Chulkov G. I. Kak rabotal Dostoevskiy [The Way Dostoevsky Worked]. Moscow, Sovetskiy pisatel' Publ., 1939. 339 p.

24. F. M. Dostojewski. Die Urgestalt der "Brüder Karamasoff". Dostojewskis Quellen, Entwürfe und Fragmente. Erläutert von W. Komarowitsch [Fyodor Dostoevsky. An Original Image of "The Brothers Karamazov". Dostoevsky's Manuscripts, Drafts and Fragments. The Comments of Vasily Komarovich]. München, R. Piper Publ., 1928. 621 p.

Дата поступления в редакиию: 10.11.2016

(C) Н. А. Тарасова, 2016 